\title{
CONSIDERATIONS ON MANAGEMENT FOR TECHNOLOGICAL ENTREPRENEURSHIP
}

\author{
Elena-Izabela Popa $^{1 *}$, Amalia Furdui ${ }^{1 *}$, and Eduard-Victor Edelhauser ${ }^{1}$ \\ ${ }^{1}$ University of Petroșani, Universității Street, No. 20, Petroșani, România
}

\begin{abstract}
The study focuses on the idea that the variations between countries regarding entrepreneurial activity and spatial structure of economies could be the source of various efficiencies in disseminating knowledge and economic growth. The study aims at developing an empirical model for both entrepreneurial activity and agglomeration effects on knowledge diffusion. The model is tested using cross-border data to measure the level of entrepreneurship in each economy. We believe that, after controlling the knowledge pool and R \& D spending, both entrepreneurial activity and agglomeration have a positive and statistically significant effect on technological change in the European Union.
\end{abstract}

\section{Introduction}

The essence of entrepreneurship is to go against time, wisely and maturely and serve as an agent of change. The entrepreneur brings innovation and creates an economic development with a positive impact on job creation.

Developing entrepreneurship in CEE countries has been uneven where Romania was a slower country in the creation of the private sector in comparison with the other countries in Europe and especially with the EU. [1]

In this article, we have used the Global Entrepreneurship Monitor (GEM) database to investigate technological entrepreneurial intent and global innovation. Also, in the paper, we will estimate some alternative data samples with EU and Romanian countries to see if there are some differences in terms of entrepreneurial activity and the spatial structure of economies for different countries or groups of countries.

In Section 2 of the paper we present the philosophy of the GEM project and of the technological entrepreneurship, defining the concepts and the methodological framework. In Section 3 we will review the literature on entrepreneurial intentions, and in the last section we will present the data, the estimation methodology, the results we have and the final conclusions.

\footnotetext{
${ }^{1}$ Corresponding author: iulia_amalia@yahoo.com
} 


\section{The conceptual framework on technological entrepreneurship and the theoretical aspects of GEM (Global Entrepreneurship Monitor)}

At present, we are living in an accelerated transition period marked by complex and profound transformations in all areas of activity. The extent of innovation is reflected primarily in the high pace of the development of new products and technologies, but the changes are not just about tangible things. Technology Entrepreneurship is at the heart of a number of important debates, including those around launching and developing companies, regional economic development, selecting stakeholders to take ideas in markets, and educate managers, engineers and scientists. Unless a generally accepted definition of technology entrepreneurship is established, but technological entrepreneurship is an investment in a project that assembles and distributes specialized individuals and heterogeneous assets to create and capture value for the firm. Entrepreneurship technology is a vehicle that facilitates prosperity in individuals, businesses, regions and nations. The technology entrepreneurship study therefore serves an important function beyond satisfying intellectual curiosity. However, we are at a time when we can capitalize on the perspectives contributed by previous work to create a clearer definition of entrepreneurship in the field of technology.

GEM is a research program initiated in 1997 by entrepreneurs in London Business School and Babson College. The first research result was published in 1999, including 10 countries. The number of participating countries has progressively increased to 42 in 2007 , 43 in 2008 and 73 countries in 2014. The main purpose of the GEM program is to study the complex relationship between entrepreneurship and economic growth by measuring the level of entrepreneurial activity in international comparison discover the factors of influence of the level of entrepreneurial activity and identify policies that can stimulate the level of entrepreneurial activity. GEM, as a research program, focuses on factors influencing economic growth and entrepreneurship, starting from the widely accepted phenomenon that entrepreneurship is one of the major forces that influence the state of the economy. The Global Entrepreneurship Monitor (GEM) is the most well-known study in the world of entrepreneurship. [2-4]

In GEM, entrepreneurship is a combination of the framework conditions and personal traits and the ability of individuals to find and take advantage of different business opportunities. the practical utility of GEM is to identify factors that stimulate or restrict entrepreneurship and is a very good tool for policy-makers to find solutions to boost entrepreneurship. In each country, an opinion poll (face-to-face or face-to-face) is conducted annually among the adult population aged 18-64. This study focuses on the characterization of entrepreneurial behavior and the attitudes of the adult population towards entrepreneurship, and in particular the Global Entrepreneurship Monitor (GMB) report analyzes the factors that determine the need for, the opportunity and the mixed motives of entrepreneurship. This report focuses on four main objectives:

- measuring the differences in levels of entrepreneurial activity between different countries,

- determining the extent to which entrepreneurial activity influences the growth and economic development of different countries,

- identifying factors that determine the level of entrepreneurial activity,

- identifying policies that can lead to higher levels of entrepreneurial activity.

Based on the data gathered through GEM studies, there are a few indicators of entrepreneurial activity that can be calculated [5]:

- the total of early-stage entrepreneurial activity (TEA) - the percentage of the 18-64-yearold adult population in the process of setting up a business, 
- established business ownership rate - the percentage of the 18-64-year-old adult population who is currently the owner of a fixed business,

- business interruption rate - the percentage of the 18-64-year-old adult who has interrupted a business in the last 12 months,

- Entrepreneurial Employee Activity (SEA) - the percentage of the 18-64-year-old adult population who, as employees, was involved in entrepreneurial activities,

- Social Entrepreneurial Activity (SEA) - the percentage of the 18-64-year-old adult population who engages in early-stage entrepreneurship with a social purpose.

The Global Competitiveness Report (GCR) is an annual report published by the World Economic Forum. Since 2004, the Global Competitiveness Report is based on Global Competitiveness Index countries, developed by Xavier Sala-i-Martin and Elsa V. Artadi. Before that, the macroeconomic ranks were based on the growth index Jeffrey Sachs, and microeconomic ranks were based on Michael Porter's competitiveness index. The Global Competitiveness Index integrates macroeconomic and micro/business aspects of competitiveness into a single index. The report assesses the ability of countries to offer their citizens a high level of prosperity. This, in turn, depends on how productive a country uses the available resources. [6,7]

According to the Global Competitiveness Report, countries can be divided into three categories according to their development phase. The production-based economy is competitive, especially due to lower prices, products being less complex, low-value and labor-intensive. Technology is assimilated, in particular, by imports and foreign direct investment. The necessary essential conditions (institutions, infrastructure, macroeconomic stability, health and primary education) are presumed. In this first stage, competitiveness is asserted by identifying those factors that can provide normative, quantitative efficiency, providing a basis for further development. In the case of investment efficiency-based economy (more efficient production, high-quality products), the conditions of competitiveness are related to higher education and continuing training, as well as the ability to benefit from existing technologies and access to new technologies. In the case of innovation-based economy, competitiveness is gained through the development and sale of new innovative technologies and products. [8]

\section{Models and Data in the EU and Romania on Entrepreneurship}

The GEM conceptual framework, identified in 1999, as opposed to the conventional national economic growth model (Fig. 1), has shown the basic assumption that national economic growth is the result of individuals (wherever they are and regardless of whether they are independent or the size of enterprises) personal identification and take advantage of opportunities and that this process takes place in interaction with the environment. Using the results of GEM surveys over the years, this initial conceptual framework has evolved $[3-5,9]$.

The purpose of GEM research was to identify the factors that determine the level of entrepreneurial activity at national level as well as the policies that encourage the increase of the activity entrepreneurshipand the creation of an entrepreneurial link with economic growth and in a longer perspective with economic development (because entrepreneurs create new businesses, new businesses create new jobs, offer a variety of products and services to the population, increase competition, increasesproductivity through technological change and have a positive impact on individual life on multiple levelsSchumpeterian point of view.

GivenWorldwide, entrepreneurship is perceived as having a high social status. Twothirds of adults think it is a good choice for a future career and more than half of the active 
population feels it has the ability to start a business-shows the Global Entrepreneurship Monitor report. [9-12]

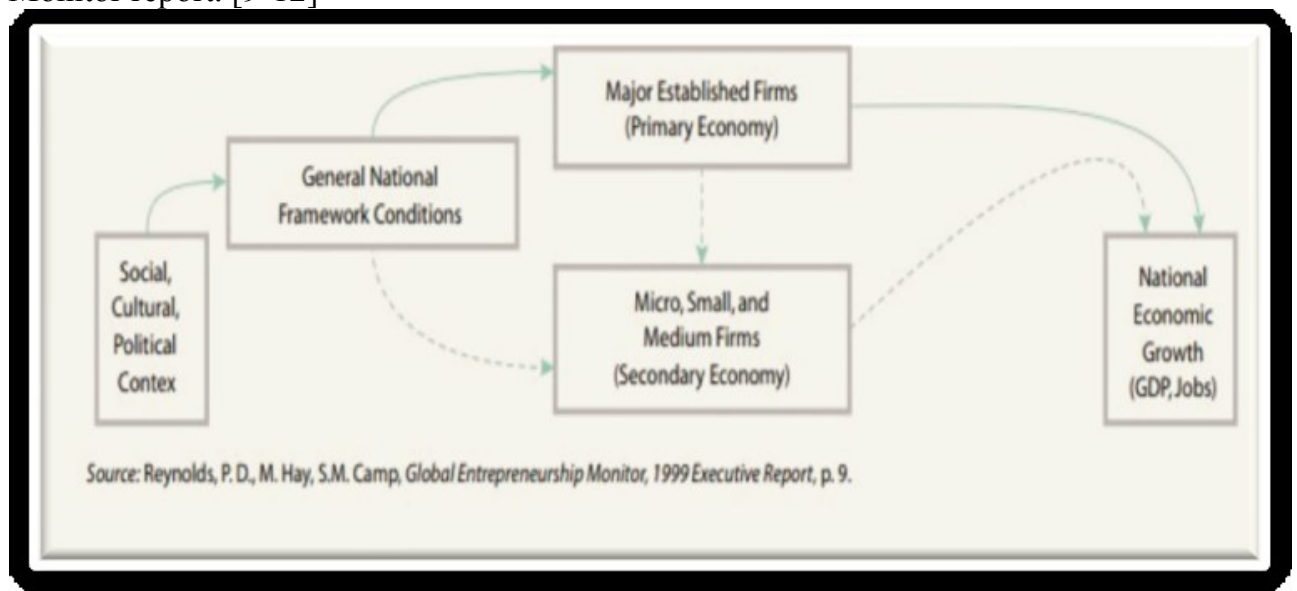

Fig.1. Conventional model of national economic growth

Entrepreneurial activities will be presented using organizational lifecycle approach (setting up, new business, established activity, interruption) by adding perspectives on entrepreneurial activity. The table shows the prevalence rate of entrepreneurial activity throughout the life stages of a company, providing information on entrepreneurial dynamics for each of the GEM economies grouped by region (Fig. 2). [3, 4]

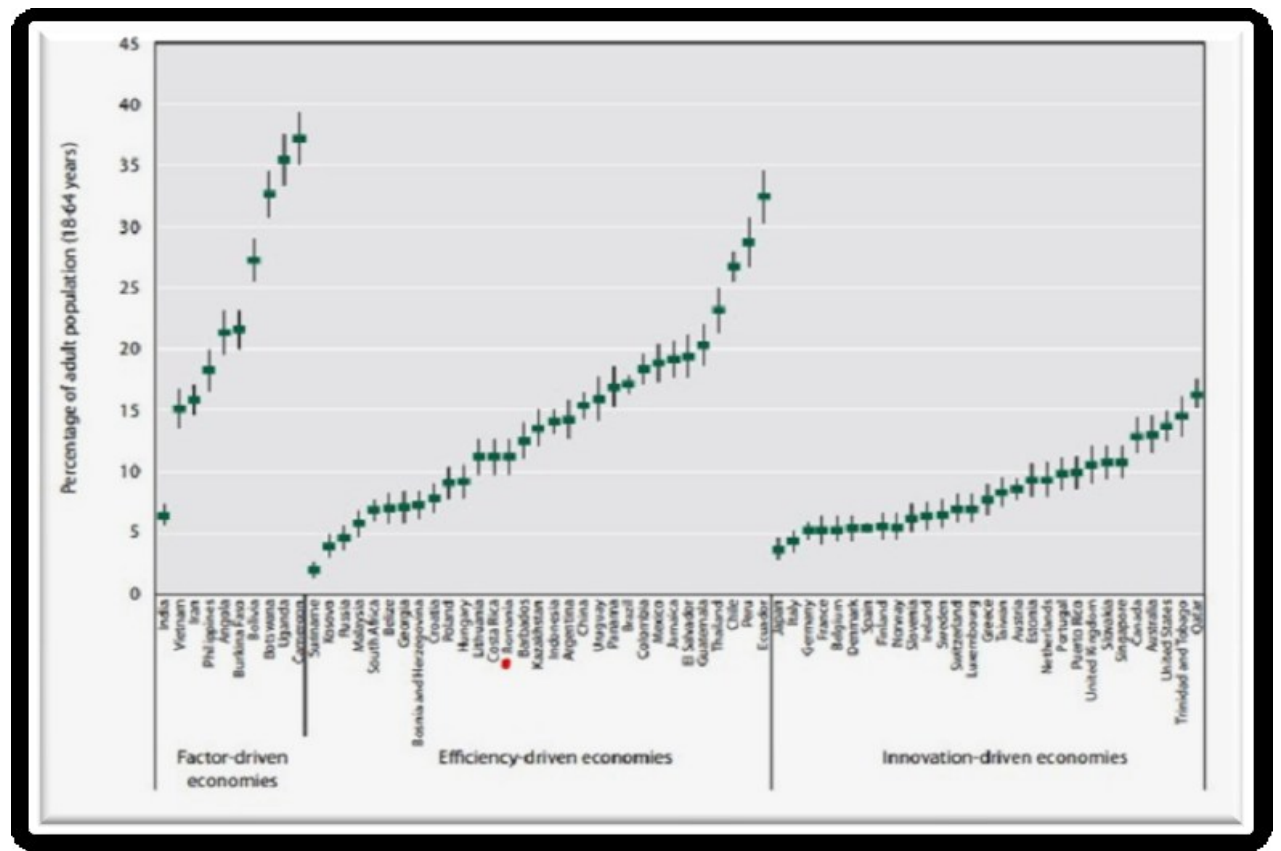

Fig. 2. Total early-stage entrepreneurial activity (TEA) in the GEM economies in 2014, by phase of economic development (where vertical bars represent 95\% confidence intervals for TEA punctual estimates). Source: Report GEM, 2014 
In Romania, the rate of start-up entrepreneurial activity (TEA) is $11 \%$ in 2015 , as it is the percentage of the active population who did something to start a business (raised money, developed a business plan, etc.) already has a company with an age of up to 3.5 years. This GEM-specific indicator tends to decrease as the economy grows. Romania ranks 2015 at the middle of the ranking (ranking 30 among the 60 countries that participated in the GEM project in 2015).As compared to 2014, Romania recorded a slight decrease of 0.5 percentage points, but still exceeds the European average of $7.8 \%$ or the TEA rate of some UE countries such as Hungary $(7.9 \%)$, Poland $(9.2 \%)$ or Bulgaria $(3.5 \%)$. Nearly a quarter of the adults in the 60 countries that are part of this investigation intend to start a business in the next three years. The percentage is $29 \%$ in Romania, which ranks 16 th in the world and well above the European average of $12.8 \%$. However, there is a slight decrease compared to 2014, when $32 \%$ of Romanians over 18 years old were interested in starting business. At the same time, the government's involvement remains very low: 48 out of 62 in terms of programs and policies to support entrepreneurship.

Most Entrepreneurial activity implies

- the GEM report shows that entrepreneurship rates also differ in stagnant economies similar economic development - not all entrepreneurial efforts seem to have the same impact on economic development.

- the data shows how much the level of development of the economy is higher, the more a starting a new business is lower (there are jobs in large and established companies).

- the role of social and cultural factors that influence entrepreneurial perceptions and attitudes.

Entrepreneurial activity in Romania, compared to other countries, is found in (Fig. 2). We used the estimates from Global Entrepreneurship Monitor [13], the most recent year with data available for Romania at individual level. Estimates are made using four data samples at individual level: one with complete global data, one with data only for Romania, one with data for CEE countries included in the GEM database and one with all the European countries in the GEM data base. The indicators used in entrepreneurial behavior are: financial support, government policies, entrepreneurial government programs, entrepreneurship education, research and development transfer, the degree of openness of the internal market, access to physical infrastructure, cultural and social norms.

Individual perceptions of entrepreneurial activity are influenced by several factors:

- perceiving opportunities in their environment,

- if they have sufficient knowledge and skills to start a new business,

- know other people involved in activities entrepreneurial

- if they prefer a uniform living standard,

- if you think new successful business is good promoted by the media,

- if they consider those who are successful in starting a business we have a high level of status and respect,

- the extent to which fear of failure stops them from engaging them inentrepreneurial activity.

Entrepreneurial behavior and attitudes in Romania can be seen in (Fig. 3) where (Expert Ratings: $1=$ highly insufficient, $5=$ high enough). $[9,10,12]$

The most recent data is from 2015 because Romania is no longer appearing in the GEM reports after this period. It can be noticed that Romania ranks between Levels 2 and 3 of Expert Ratings, an average level compared to other member states EU. 


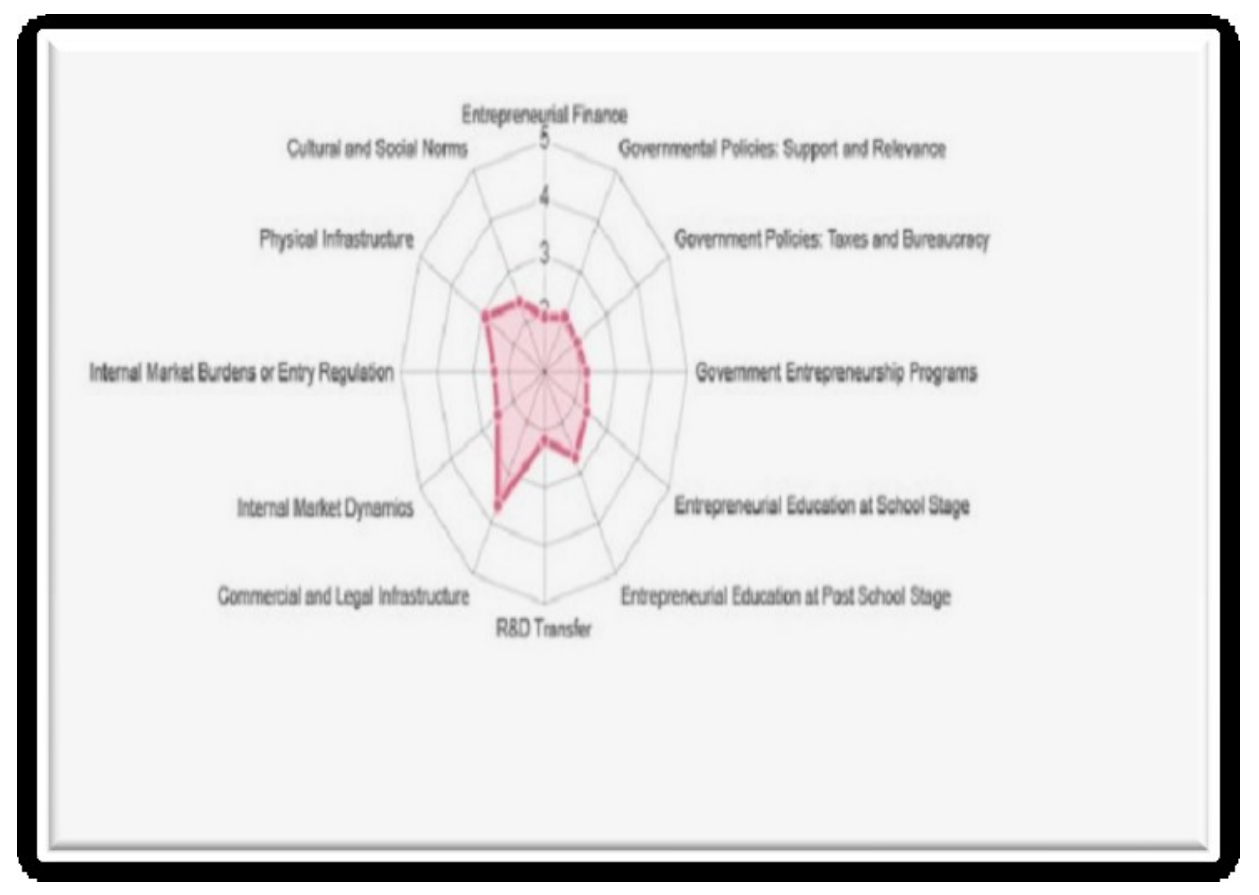

Fig. 3. Entrepreneurial Framework Conditions (EFC)

Entrepreneurial framework conditions (EFC) are explained below:

EFC1: Financial Support - Availability of financial resources, shares and debts, for new and emerging firms, including allocations and grants.

EFC2: Government Policies-The extent to which government policies, reflected in taxes or regulations, or their application, are neutral in terms of size, or encourage new and emerging firms.

EFC3: Governmental Entrepreneurship Programs - Presence and Quality direct programs to help new and emerging companies at all government levels.

EFC4: Entrepreneurial Education-The degree of improvement in the field creating or managing small, new or emerging firms is incorporated into the education and training system at all levels.

EFC5: Transfer of Research and Development The extent to which national research and development will lead to the emergence of new opportunities commercial.

EFC6: Commercial and Legal Infrastructure. The presence of commercial, accounting and other legal services and institutions that allow or promote the emergence of new, small or emerging businesses.

EFC7: Opening up of the internal market. There are two distinct sub-dimensions of these EFCs: market change, in the degree in which markets are changing dramatically from year to year, and the degree of market opening.

EFC8: Access to Physical Infrastructure Ease of access to available physical resources communication, facilities, transportation, landor space - at a price that does not discriminate against new, small or developing firms.

EFC9: Cultural and Social Standards. The extent to which existing cultural and social standards encourage, or do not discourage, individual actions that can lead to the emergence of new ways of doing business.

We have used in the paper the multinomial logistic model to estimate the equation between different reasons for entrepreneurial intent and explanatory variables. In the case of sub-indices of entrepreneurial intent, we used binary logistic models. Logistic models 
were applied to 4 data samples, one with full data available in the GEM database one covering the countries of Europe with the sample of Romania and one with all EU member states covered by GEM. [4]

\section{Conclusions}

In this article the main purpose of the paper was to investigate the technological entrepreneurial intentions and innovation at international level as well as the entrepreneurial activity on the spatial structure of economies using the GEM database. In particular, we examined the factors that determine the need-the opportunity-and motivating entrepreneurship. We also used database basic Global Entrepreneurship Monitor (GEM) and Global Competitiveness Report (GCR). The Global Entrepreneurship Monitor (GEM) is the most important and comprehensive international study of entrepreneurship and the environment. According to the reports, GEM highlights the different stages of economic development that a country can go through and claims that the activity of large firms changes according to the general conditions of the national framework and the entrepreneurial activity according to the conditions of the entrepreneurial framework. The Global Competitiveness Report (GCR) is an annual report published by the World Economic Forum since 2004. According to the Global Competitiveness Report (GCR) evaluations, 37 countries have innovation driven savings, with the most advanced being Switzerland, Singapore, Finland, Germany, USA, Sweden, Hong Kong, the Netherlands, Japan and the United Kingdom. places the top ten positions in the world ranking after the overall competitiveness index. Of note, 21 states are members of the European Union are part of this group. Another 31 countries are in the category of efficiency-driven economies, with Romania being included among other countries in the region, such as Bulgaria, Serbia, Albania, and so on. The third category is factor-driven economies, present in 38 countries on all continents, less in Europe. [5, 12]

In conclusion, for stimulating the entrepreneurial spirit for each analyzed country is the support given to governmental policies and to entrepreneurship in general. In Romania, the recommendation is to provide financial support for entrepreneurship, followed by improved education and entrepreneurial training.

\section{References}

1. M. Gerber, Mitul întreprinzătorului, (Editura Amaltea, București, 2003)

2. ***,https://www.gemconsortium.org/report/49079, (accessed on 05.01.2019)

3. ***,https://www.gemconsortium.org/country-profile/103, accessed on (15.01.2019)

4. ***Romanian Journal of Economic Forecasting-XXI (1) (2018), http://www.ipe.ro/rjef.htm, (accessed on 15.02.2019)

5. ***,https://www.researchgate.net/publication/310799689_ENTREPRENEURSHIP_IN_ROMA NIA COUNTRY REPORT 2014, (accessed on 15.02.2019)

6. Dézsi-Benyovszki Annamaria, Agnes Nagy, Szabó Tunde Petra, Entrepreneurship In Romania Country Report 2014, (accessed on 15.02.2019)

7. E. Edelhauser, Fii antreprenor, fii activ în S.A.S UPET!, http://www.cnfis.ro/rezultate-evaluarefdi-2017/

8. Estrin, S. Meyer, K.E. and M. Bytchkova, Entrepreneurship in transition economies. In Global Entrepreneurship Monitor, GEM Global Report 2017-2018, Available at: www.gemconsortium.org (2018)

9. S. Singer, J. E. Amorós, D. M. Arreola, Global Entrepreneurship Monitor 2014 - Global Report, Babson College, Universidad del Desarrollo, Universiti Tun Abdul Razak, Technológico de Monterrey, London Business School and Global Entrepreneurship Research Consortium (GERA) (2015) 
10. K. Schwab, The Global Competitiveness Report 2009-2010, World Economic Forum, Geneva, Switzerland (2009)

11. ***,https://www.gemconsortium.org/, (accessed on 05.01.2019)

12. ***,https://en.wikipedia.org/wiki/Global_Competitiveness_Report, (accessed on 15.01.2019)

13. ***,http://www.ebirouvirtual.ro/sites/default/files/articole_bv/131216\%20Studiu $\% 20$ competitivi tate\%20inovare.pdf, (accessed on 15.01.2019) 